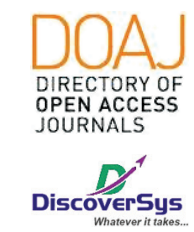

Published by DiscoverSys

\title{
Larutan pencuci hidung salin isotonis tidak terbukti mempercepat waktu transpor mukosilia pada pasien dengan rinosinusitis akut di RSUP Sanglah, Bali, Indonesia
}

\author{
Ni Putu Oktaviani Rinika Pranitasari, ${ }^{1 *}$ Luh Made Ratnawati, ${ }^{1}$ I Nyoman Adiputra ${ }^{2}$
}

\section{ABSTRACT}

Background: Mucociliary clearance is a significant element of the defence system of the entire respiratory tract. Impairment of the mucociliary clearance serves as a medium for sinonasal infections. Saline nasal irrigation is believed to alleviated rhinosinusitis symptoms by clearing excess mucus, reducing congestion and remove infectious materials from the inspired air. This study aimed to determine the efficacy of mucociliary transport time of isotonic saline nasal solutions in patients with acute rhinosinusitis.

Methods: An experimental study using pre- and post-test with control group design was conducted in this study. Mucociliary transport time was measured by the saccharine test on 20 acute rhinosinusitis patients before and after 7 days' treatment with intranasal isotonic saline solutions and standard therapy (ciprofloxacin, pseudoephedrine/ triprolidine, ambroxol) for the case group and standard treatment for the control group. Data were analysed using SPSS version 20 for Windows.

Result: The average mucociliary transport time before therapy was $35.5 \pm 10.7$ minutes and $29.2 \pm 7.7$ minutes for the case group and control group, respectively. The average mucociliary transport time after therapy was $22.9 \pm 8.7$ minutes and $18.0 \pm 5.6$ minutes for case group and control group, respectively. The mean difference mucociliary transport time before and after therapy was $11.0 \pm 7.5$ minutes and $9.4 \pm 5.3$ minutes for the case and control group, respectively $(p=0.499)$.

Conclusions: The addition of intranasal isotonic saline solutions in acute rhinosinusitis patients has the same effect of mucociliary transport time with oral medication with the antibiotic, decongestant, and mucolytic without intranasal isotonic saline solutions.

Keyword: Isotonic Saline, Acute Rhinosinusitis, Mucociliary Clearance.

Cite This Article: Pranitasari, N.P.O.R., Ratnawati, L.M., Adiputra, I.N. 2020. Larutan pencuci hidung salin isotonis tidak terbukti mempercepat waktu transpor mukosilia pada pasien dengan rinosinusitis akut di RSUP Sanglah, Bali, Indonesia. Intisari Sains Medis 11(1): 145-152. D0I: 10.15562/ism.v11i1.587

ABSTRAK

Latar Belakang: Transpor mukosilia merupakan salah satu mekanisme pertahanan saluran pernapasan. Adanya gangguan pada sistem tersebut menjadi predisposisi terjadinya infeksi sinonasal. Larutan pencuci hidung dengan salin isotonis dipercaya dapat mengurangi gejala akibat rinosinusitis dengan cara membersihkan sekret, mengurangi odema dan mengeluarkan bahan-bahan berbahaya yang masuk bersama udara pernapasan. Tujuan penelitian ini adalah untuk menilai efektivitas waktu transpor mukosilia larutan pencuci hidung salin isotonis pada pasien rinosinusitis akut.

Metode: Uji eksperimental dengan desai pre-post test dengan kontrol dilakukan pada penelitian ini. Waktu transpor mukosilia diukur menggunakan uji sakarin terhadap 20 pasien rinosinusitis akut sebelum dan 7 hari sesudah pemberian larutan pencuci hidung salin isotonis dan terapi standar (ciprofloxacine, pseudoephedrine) triprolidine, ambroxol) pada Kelompok Perlakuan dan terapi standar pada Kelompok Kontrol. Data dianalisis menggunakan SPSS versi 20 untuk Windows.

Hasil: Rerata waktu transpor mukosilia sebelum perlakuan pada Kelompok Perlakuan adalah 35,5 \pm 10,7 menit dan 29,2 \pm 7,7 menit pada Kelompok Kontrol. Rerata waktu transpor mukosilia sesudah terapi adalah $22,9 \pm 8,7$ menit dan 18,0 $\pm 5,6$ menit berturut-turut pada Kelompok Perlakuan dan Kelompok Kontrol. Median selisih waktu transpor mukosilia sebelum dan sesudah terapi adalah $11,0 \pm 7,5$ menit pada Kelompok Perlakuan dan 9,4 \pm 5,3 menit pada Kelompok Kontrol $(p=0,499)$.

Kesimpulan: Penambahan larutan cuci hidung salin isotonis pada rinosinusitis akut memiliki efek waktu transpor mukosilia yang sama dengan pemberian antibiotika, dekongestan dan mukolitik tanpa larutan cuci hidung salin isotonis.
Tenggorokan, Fakultas Kedokteran Universitas Udayana, RSUP Sanglah, Bali, Indonesia;

rinika.ps@gmail.com
Kata kunci: Salin Isotonis, Rinosinusitis Akut, Transpor Mukosilia.

Cite Pasal Ini: Pranitasari, N.P.O.R., Ratnawati, L.M., Adiputra, I.N. 2020. Larutan pencuci hidung salin isotonis tidak terbukti mempercepat waktu transpor mukosilia pada pasien dengan rinosinusitis akut di RSUP Sanglah, Bali, Indonesia. Intisari Sains Medis 11(1): 145-152. D0I: 10.15562/ ism.v11i1.587 


\section{PENDAHULUAN}

Saluran pernapasan merupakan bagian tubuh pertama yang berhubungan langsung dengan lingkungan luar. Secara fisiologis hidung merupakan salah satu organ pernapasan yang berfungsi sebagai penyaring dan pertahanan lini pertama terhadap partikel inspirasi. Silia epitel respiratorius, kelenjar penghasil mukus dan palut lendir membentuk mekanisme pertahanan dalam sistem pernapasan yang dikenal sebagai sistem mukosilia.

Fungsi mukosilia yang efektif tergantung pada tiga komponen yaitu palut lendir, gerakan silia dan sel goblet. Gangguan pada jumlah dan pergerakan silia serta produksi palut lendir akan menyebabkan gangguan transpor mukosilia hidung. ${ }^{1}$ Penilaian fungsi transpor mukosilia dapat dilakukan dengan uji sakarin yang sederhana, non invasif, mudah, murah dan merupakan pemeriksaan baku emas untuk uji perbandingan. ${ }^{1,2}$ Transpor mukosilia akan memanjang pada infeksi saluran napas atas, rinitis alergi dan rhinosinusitis. ${ }^{3}$ Pada rinosinusitis fungsi muko-silia terganggu karena perubahan kualitas dan kuantitas rheologi mukus atau kerusakan pada epitel bersilia hidung dan sinus paranasal., ${ }^{4,5}$

Rinosinusitis akut adalah inflamasi pada mukosa kavum nasi dan sinus paranasal dalam waktu 4 minggu atau kurang dengan gejala hidung buntu, nyeri pada wajah, ingus kental dan post nasal drip purulen. Rinosinusitis akut membawa dampak ekonomi berupa tingginya biaya pengobatan dan menurunnya produktivitas kerja akibat banyaknya pekerja yang absen. ${ }^{6}$ Sinus paranasal merupakan kelanjutan saluran pernapasan bagian atas dan sebanyak 0,5\%-2\% infeksi saluran napas atas berkembang menjadi rinosinusitis. ${ }^{7,8}$ Di Indonesia, infeksi saluran napas atas merupakan penyakit yang sering ditemukan, demikian pula dengan rinosinusitis akut yang banyak dijumpai meskipun belum terdiagnosis, sehingga angka kejadiannya belum jelas dan belum banyak dilaporkan. ${ }^{9}$

Diagnosis rinosinusitis akut didapatkan melalui anamnesis, pemeriksaan fisik dan pemeriksaan radiologi. ${ }^{10}$ Penatalaksanaan rinosinusitis akut berupa pemberian obat-obatan meliputi: antibiotika, dekongestan oral/topikal, mukolitik maupun tindakan pembedahan. ${ }^{10,11}$ Pencucian hidung dengan menggunakan larutan salin telah lama dikenal sebagai terapi tambahan pada rinosinusitis, rinitis alergi maupun pascapembedahan sinus. ${ }^{12}$ Pencucian hidung dengan larutan salin dapat memperbaiki drainase sinus dan fungsi mukosilia hidung, mengurangi mediator inflamasi, mempercepat penyembuhan mukosa dan mencegah perlengketan mukosa pascapembedahan. ${ }^{13,14}$ Penggunaan larutan salin sebagai pencuci hidung juga dapat mengurangi waktu penggunaan antibiotika sehingga dapat meningkatkan kepatuhan pasien dan mengurangi biaya pengobatan. ${ }^{13}$

Manfaat cuci hidung dengan larutan salin pada rinosinusitis kronis telah banyak dipublikasikan sedangkan penggunaan larutan cuci hidung salin pada kasus rinosinusitis akut masih kontroversial. ${ }^{15}$ Inanli S et al tahun 2002 menyatakan tidak ada perbedaan waktu transpor mukosilia yang signifikan pada rinosinusitis akut yang mendapat terapi amoxicillin/clavulanic acid dibandingkan dengan amoxicillin/clavulanic acid dan larutan cuci hidung salin isotonis. ${ }^{3}$ Sementara itu penelitian Ural A et al tahun 2009 menunjukkan perbedaan yang signifikan terhadap waktu transpor mukosilia sebelum dan sesudah pemberian larutan cuci hidung salin isotonis pada rinosinusitis akut. ${ }^{16}$ Penelitian mengenai manfaat penggunaan larutan cuci hidung salin isotonis pada rinosinusitis akut masih sangat terbatas. ${ }^{17}$ Berkaitan dengan hal tersebut maka penelitian ini bertujuan untuk mengetahui efektivitas larutan salin isotonis sebagai terapi tambahan pada rinosinusitis akut.

\section{METODE PENELITIAN}

Penelitian ini menggunakan rancangan penelitian eksperimental, desain pre-post test dengan kelompok kontrol yang dilakukan pada Poliklinik THT RSUP Sanglah, Denpasar pada bulan Agustus Desember 2014. Populasi target adalah semua pasien rinosinusitis akut. Populasi terjangkau adalah semua pasien rinosinusitis akut yang berobat ke Poliklinik THT-KL RSUP Sanglah, Denpasar. Pengambilan sampel pada Kelompok Perlakuan maupun Kelompok Kontrol dilakukan secara berurutan (consecutive sampling), yaitu setiap pasien yang memenuhi kriteria inklusi penelitian dimasukkan dalam sampel penelitian sampai kurun waktu tertentu hingga jumlah sampel yang diperlukan telah dipenuhi. Sampel yang bersedia mengikuti prosedur penelitian kemudian menandatangani informed consent dan selanjutnya ditetapkan sebagai sampel penelitian.

Pemilihan Kelompok Perlakuan maupun Kelompok Kontrol pada sampel dilakukan secara random dengan teknik randomisasi blok. Subjek akan mendapat pengobatan A yaitu terapi standar berupa antibiotika ciprofloxacin $2 \times 500 \mathrm{mg}$, dekongestan pseudoephedrine $60 \mathrm{mg} /$ triprolidine $\mathrm{HCl} 2,5 \mathrm{mg} 3 \times 1$ tablet dan mukolitik ambroxol $3 \times 30 \mathrm{mg}$ selama 7 hari atau pengobatan B yaitu terapi standar ditambah larutan pencuci hidung salin isotonis, sesuai dengan nomor amplop yang telah ditentukan secara randomisasi blok. Jumlah sampel penelitian adalah 36 responden dimana terbagi atas 18 kelompok kontrol dan 18 kelompok perlakuan. Adapun kriteria inklusi pada penelitian 
ini adalah usia 15 - 60 tahun dan kooperatif, terdiagnosis rinosinusitis akut, serta bersedia mengikuti penelitian dengan menandatangani informed consent. Sedangkan kriteria eksklusi pada penelitian ini adalah pasien yang menderita polip hidung, tumor sinonasal, gangguan pengecap, hipertensi, riwayat pengobatan dengan dekongestan dalam 2 hari terakhir, dan adanya riwayat operasi hidung dan sinus paranasal dalam 3 bulan terakhir.

Larutan pencuci hidung salin isotonis pada penelitian ini adalah larutan pencuci hidung yang mengandung $\mathrm{NaCl}$ 0,9\% dikemas dalam botol infus $500 \mathrm{ml}$ yang diberikan dengan cara disemprotkan ke dalam kavum nasi menggunakan syringe $10 \mathrm{ml}$ dengan dosis pemberian $3 \times 10 \mathrm{ml}$ selama 7 hari. Uji Sakarin yang dipergunakan pada penelitian ini adalah uji yang dilakukan untuk mengukur waktu transpor mukosilia menggunakan tablet sakarin merk Equal berukuran diameter $1 \mathrm{~mm}$ yang diletakkan $1 \mathrm{~cm}$ di belakang ujung anterior konka inferior menggunakan forsep aligator. Sedangkan waktu transpor mukosilia adalah waktu yang dibutuhkan oleh tablet sakarin mulai saat diletakkan $1 \mathrm{~cm}$ di belakang ujung anterior konka inferior sampai ke nasofaring yang ditandai rasa manis di tenggorok dalam satuan menit yang diukur menggunakan stopwatch. Waktu transpor mukosilia dibagi menjadi waktu transpor mukosilia sebelum perlakuan yang diukur sebelum pemberian terapi dan waktu transpor mukosilia sesudah perlakuan yang diukur 7 hari setelah pemberian terapi.

Hasil penelitian disajikan secara deskriptif, yaitu dalam bentuk persentase untuk data umur, jenis kelamin dan indeks massa tubuh. Uji normalitas data waktu transpor mukosilia sebelum perlakuan pada Kelompok Perlakuan dan Kelompok Kontrol dilakukan dengan uji Shaphiro-Wilk. Data waktu transpor mukosilia sebelum perlakuan pada ke dua kelompok berdistribusi tidak normal, sehingga dilakukan analisis terhadap nilai selisih waktu transpor mukosilia sebelum dan sesudah perlakuan pada ke dua kelompok. Normalitas data selisih waktu transpor mukosilia sebelum dan sesudah perlakuan pada ke dua kelompok menunjukkan data berdistribusi tidak normal, sehingga selanjutnya uji perbandingan dilakukan menggunakan uji Mann-Whitney. Data dianalisis menggunakan piranti lunak SPSS versi 20 untuk Windows.

\section{HASIL PENELITIAN}

Umur subjek dalam penelitian ini dibagi menjadi empat kategori dengan frekuensi terbanyak pada Kelompok Perlakuan adalah umur 15-25 tahun dan 36-45 tahun yaitu masing-masing sebesar $30 \%$, sedangkan pada Kelompok Kontrol frekuensi terbanyak adalah umur 26-35 tahun, yaitu sebesar 50\%. Terdapat perbedaan rerata umur antara Kelompok Perlakuan dengan Kelompok Kontrol, dimana rerata umur pada Kelompok Perlakuan adalah $33,5 \pm 11,8$ menit dan rerata umur pada Kelompok Kontrol adalah $30,3 \pm 8,8$ menit. Perbedaan rerata umur tersebut tidak bermakna secara statistik dengan nilai $\mathrm{p}=0,338$ (Tabel 1 ).

Sebanyak 75\% subjek pada Kelompok Perlakuan berjenis kelamin laki-laki sedangkan pada Kelompok Kontrol sebanyak 60\% subjek berjenis kelamin perempuan. Terdapat perbedaan distribusi proporsi jenis kelamin yang bermakna secara statistik dengan nilai $\mathrm{p}=0,025$ (Tabel 1 ).

Indeks massa tubuh subjek penelitian sebagian besar adalah normal yaitu sebesar 30\% pada Kelompok Perlakuan dan 45\% pada Kelompok Kontrol. Rerata indeks massa tubuh pada Kelompok Perlakuan adalah 23,8 $\pm 3,8 \mathrm{~kg} / \mathrm{m}^{2}$ sedangkan pada Kelompok Kontrol adalah $23,4 \pm 4,3 \mathrm{~kg} / \mathrm{m}^{2}$. Perbedaan rerata indeks massa tubuh tersebut tidak bermakna secara statistik dengan nilai $\mathrm{p}=0,748$. Subjek yang merokok pada Kelompok Perlakuan sebesar 5\% dan pada Kelompok Kontrol sebanyak $2 \%$ dan perbedaan distribusi proporsi status merokok tersebut tidak bermakna secara statistik dengan nilai $\mathrm{p}=0,212$ (Tabel 1$)$.

Sebagian besar subjek mengeluh ke dua hidung tersumbat yaitu sebanyak $75 \%$ pada Kelompok Perlakuan dan $70 \%$ pada Kelompok Kontrol (Tabel 2). Gejala lain yang dikeluhkan oleh pasien meliputi: pilek pada semua subjek ke dua kelompok (100\%), nyeri pipi sebanyak $30 \%$ pada Kelompok Perlakuan dan 20\% pada Kelompok Kontrol, sakit kepala sebanyak $75 \%$ pada ke dua kelompok, dan gangguan penghidu sebanyak 35\% pada Kelompok Perlakuan dan $45 \%$ pada Kelompok Kontrol (Tabel 2). Selain itu, gejala demam ditemukan sebanyak 25\% pada Kelompok Perlakuan dan 10\% pada Kelompok Kontrol, napas berbau sebanyak $20 \%$ pada Kelompok Perlakuan dan 15\% pada Kelompok Kontrol, dahak di tenggorok sebanyak 85\% pada Kelompok Perlakuan dan 80\% pada Kelompok Kontrol (Tabel 2).

Keluhan lain yang dirasakan subjek adalah batuk sebanyak 25\% pada Kelompok Perlakuan dan 15\% pada Kelompok Kontrol, nyeri telinga sebanyak 5\% pada Kelompok Perlakuan, rasa penuh pada telinga sebanyak 5\% pada Kelompok Perlakuan dan 10\% pada Kelompok Kontrol (Tabel 2). Sebagian besar kelompok perlakuan juga menunjukkan tidak terdapat deviasi septum nasi $(60,0 \%)$, begitupula pada kelompok kontrol $(70,0 \%)$ dimana tidak bermakna secara statistik (Tabel 2).

Rerata waktu transport mukosila sebelum perlakuan pada Kelompok Perlakuan adalah $35,5 \pm 10,7$ menit dan pada Kelompok Kontrol adalah $29,2 \pm 7,7$ menit seperti ditampilkan pada 
Tabel 1 Karakteristik responden berdasarkan kelompok perlakuan

Kelompok $(\mathrm{N}=40)$

\begin{tabular}{|c|c|c|c|}
\hline Karakteristik & Perlakuan $(\mathrm{N}=\mathbf{2 0})$ & Kontrol ( $\mathrm{N}=\mathbf{2 0})$ & Nilai-P \\
\hline Umur $($ rerata $\pm S B)$ & $33,5 \pm 11,8$ & $30,3 \pm 8,8$ & $0,338^{\mathrm{a}}$ \\
\hline 15-25 tahun & $6(30,0)$ & $5(25,0)$ & \\
\hline 26-35 tahun & $4(20,0)$ & $10(50,0)$ & $0,182^{\mathrm{b}}$ \\
\hline 36-45 tahun & $6(30,0)$ & $4(20,0)$ & \\
\hline 46-55 tahun & $4(20,0)$ & $1(5,0)$ & \\
\hline \multicolumn{4}{|l|}{ Jenis kelamin (\%) } \\
\hline Laki-laki & $15(75,0)$ & $8(40,0)$ & $0,025^{b^{*}}$ \\
\hline Perempuan & $5(25,0)$ & $12(60,0)$ & \\
\hline Indeks massa tubuh $($ rerata $\pm \mathrm{SB})$ & $23,8 \pm 3,8$ & $23,4 \pm 4,3$ & $0,748^{\mathrm{a}}$ \\
\hline Underweight & $2(10,0)$ & $1(5,0)$ & \\
\hline Normal & $6(30,0)$ & $9(45,0)$ & \\
\hline Overweight & $5(25,0)$ & $2(10,0)$ & $0,682^{b}$ \\
\hline Obese & $6(30,0)$ & $7(35,0)$ & \\
\hline Obese 2 & $1(5,0)$ & $1(5,0)$ & \\
\hline \multicolumn{4}{|l|}{ Status merokok } \\
\hline Merokok & $5(25,0)$ & $2(10,0)$ & $0,212^{\mathrm{b}}$ \\
\hline Tidak merokok & $15(75,0)$ & $18(90,0)$ & \\
\hline
\end{tabular}

${ }^{a}$ Independent T-Test; ${ }^{b}$ Pearson Chi Square Test; “Bermakna apabila P $<0,05$; SB: Simpang baku

Tabel 2 Gejala klinis dan keluhan responden penelitian berdasarkan kelompok perlakuan

\begin{tabular}{|c|c|c|c|}
\hline \multirow[b]{2}{*}{ Karakteristik } & \multicolumn{2}{|c|}{ Kelompok $(\mathrm{N}=40)$} & \multirow[b]{2}{*}{ Nilai-P } \\
\hline & Perlakuan $(\mathrm{N}=\mathbf{2 0})$ & Kontrol $(\mathrm{N}=20)$ & \\
\hline \multicolumn{4}{|c|}{ Hidung tersumbat $(\mathrm{n}, \%)$} \\
\hline Hidung kanan & $2(10,0)$ & $3(15,0)$ & $0,889^{\mathrm{a}}$ \\
\hline Hidung kiri & $3(15,0)$ & $3(15,0)$ & \\
\hline Keduanya & $15(75,0)$ & $14(70,0)$ & \\
\hline Tidak tersumbat & $0(0,0)$ & $0(0,0)$ & \\
\hline \multicolumn{4}{|l|}{ Pilek (n,\%) } \\
\hline Ya & $20(100,0)$ & $20(100,0)$ & - \\
\hline Tidak & $0(0,0)$ & $0(0,0)$ & \\
\hline \multicolumn{4}{|l|}{ Nyeri pipi (n,\%) } \\
\hline Ya & $6(30,0)$ & $4(20,0)$ & $0,465^{\mathrm{a}}$ \\
\hline Tidak & $14(70,0)$ & $16(80,0)$ & \\
\hline \multicolumn{4}{|l|}{ Sakit kepala (n,\%) } \\
\hline Ya & $15(75,0)$ & $15(75,0)$ & $1,000^{\mathrm{a}}$ \\
\hline Tidak & $5(25,0)$ & $5(25,0)$ & \\
\hline \multicolumn{4}{|c|}{ Gangguan penghidu (n,\%) } \\
\hline Ya & $7(35,0)$ & $9(45,0)$ & $0,519^{\mathrm{a}}$ \\
\hline Tidak & $13(65,0)$ & $11(55,0)$ & \\
\hline \multicolumn{4}{|l|}{ Demam (n,\%) } \\
\hline $\mathrm{Ya}$ & $5(25,0)$ & $2(10,0)$ & $0,212^{\mathrm{a}}$ \\
\hline Tidak & $15(75,0)$ & $18(90,0)$ & \\
\hline
\end{tabular}




\begin{tabular}{|c|c|c|c|}
\hline \multirow[b]{2}{*}{ Karakteristik } & \multicolumn{2}{|c|}{ Kelompok ( $\mathrm{N}=40)$} & \multirow[b]{2}{*}{ Nilai-P } \\
\hline & Perlakuan ( $\mathbf{N = 2 0 )}$ & Kontrol $(\mathrm{N}=\mathbf{2 0})$ & \\
\hline \multicolumn{4}{|l|}{ Napas berbau (n,\%) } \\
\hline Ya & $4(20,0)$ & $3(15,0)$ & $0,677^{\mathrm{a}}$ \\
\hline Tidak & $16(80,0)$ & $17(85,0)$ & \\
\hline \multicolumn{4}{|c|}{ Dahak di tenggorok (n,\%) } \\
\hline Ya & $17(85,0)$ & $16(80,0)$ & $0,677^{\mathrm{a}}$ \\
\hline Tidak & $3(15,0)$ & $4(20,0)$ & \\
\hline \multicolumn{4}{|l|}{ Keluhan lain (n,\%) } \\
\hline Batuk & $5(25,0)$ & $3(15,0)$ & $0,577^{\mathrm{a}}$ \\
\hline Nyeri telinga & $1(5,0)$ & $0(0,0)$ & \\
\hline Penuh di telinga & $1(5,0)$ & $2(10,0)$ & \\
\hline Tidak ada & $13(65,0)$ & $15(75,0)$ & \\
\hline \multicolumn{4}{|l|}{ Deviasi septum (n,\%) } \\
\hline Deviasi ke kiri & $3(15,0)$ & $4(20,0)$ & $0,348^{\mathrm{a}}$ \\
\hline Deviasi ke kanan & $2(10,0)$ & $2(10,0)$ & \\
\hline Bentuk S & $3(15,0)$ & $0(0,0)$ & \\
\hline Tidak deviasi & $12(60,0)$ & $14(70,0)$ & \\
\hline
\end{tabular}

aPearson Chi Square Test; *Bermakna apabila $\mathrm{P}<0,05$;

Tabel 3 Hasil analisis perbedaan rerata waktu transpor mukosilia sebelum dan sesudah perlakuan pada masing-masing Kelompok Perlakuan

\begin{tabular}{|c|c|c|c|c|c|}
\hline \multirow[b]{2}{*}{ Variabel } & \multicolumn{2}{|c|}{ Kelompok ( $\mathrm{N}=40)$} & \multirow{2}{*}{$\begin{array}{l}\text { Beda } \\
\text { Rerata }\end{array}$} & \multirow[b]{2}{*}{$95 \%$ IK } & \multirow[b]{2}{*}{ Nilai $\mathbf{P}$} \\
\hline & Perlakuan $(\mathrm{N}=\mathbf{2 0})$ & Kontrol $(\mathrm{N}=20)$ & & & \\
\hline \multicolumn{6}{|l|}{ Waktu transpor mukosilia (Menit) } \\
\hline Sebelum Perlakuan & $35,5 \pm 10,7$ & $29,2 \pm 7,7$ & 6,3 & $0,366-12,290$ & $0,038^{\mathrm{a}}$ \\
\hline Setelah Perlakuan & $22,9 \pm 8,7$ & $18,0 \pm 5,6$ & 5,0 & $0,249-9,703$ & $0,040^{\mathrm{a}}$ \\
\hline $\begin{array}{l}\text { Selisih waktu transport mukosilia } \\
\text { (Median, IQR) }\end{array}$ & $11,0(7,5)$ & $9,4(5,3)$ & - & - & $0,499^{\mathrm{b}}$ \\
\hline
\end{tabular}

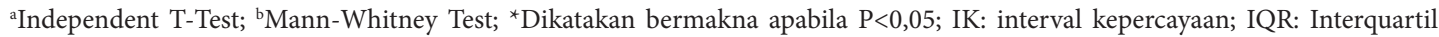
Range

Tabel 3. Beda rerata waktu transport mukosilia sebelum perlakuan pada Kelompok Perlakyan dan Kelompok Kontrol adalah 6,3 menit dengan asumsi 95\% Interval Kepercayaan sebesar 0,366-12,290 adalah berbeda bermakna ( $\mathrm{p}=0,038)$ (Tabel 3). Rerata waktu transpor mukosilar sesudah perlakuan pada Kelompok Perlakuan adalah 22,9 $\pm 8,7$ menit dan 18,0 $\pm 5,6$ menit pada Kelompok Kontrol, seperti ditampilkan pada Gambar 5.1B. Beda rerata waktu transpor mukosilia sesudah perlakuan pada Kelompok Perlakuan dan Kelompok Kontrol adalah 5,0 menit dengan asumsi 95\% Interval Kepercayaan sebesar 0,249-9,703 dimana didapatkan hasil yang berbeda bermakna $(\mathrm{p}=0,040)$ (Tabel 3). Nilai median selisih waktu transpor mukosilia hidung sebelum dan sesudah perlakuan pada Kelompok Perlakuan adalah $11,0 \pm 7,5$ menit dan 9,4 $\pm 5,3$ menit pada Kelompok Kontrol. Perbedaan tersebut secara statistik tidak bermakna dengan $(\mathrm{p}=0,499)$ (Tabel 3).

\section{PEMBAHASAN}

Pada penelitian ini rentang usia yang dipilih adalah usia 15 tahun sampai 55 tahun yaitu usia remaja sampai dewasa muda yang tingkat kooperatifnya baik serta untuk meminimalisir bias oleh karena umur. Sakakura Y et al menyatakan tidak adanya perbedaan waktu transpor mukosilia hidung pada subjek yang berusia $<60$ tahun, demikian pula penelitian oleh Homer $J$ et al yang menyatakan tidak ada perbedaan yang bermakna antara usia dengan waktu transpor mukosilia hidung. ${ }^{18,19}$

Sebagian besar subjek pada Kelompok Perlakuan berjenis kelamin laki-laki (75\%) sedangkan pada Kelompok Kontrol berjenis kelamin perempuan 
(60\%). Beberapa peneliti menyatakan tidak ada perbedaan yang signifikan mengenai jenis kelamin terhadap waktu transpor mukosilia hidung..$^{19,20}$ Valdez RJL dan Cruz EZ tahun 2009 menyatakan adanya perlambatan waktu transpor mukosilia pada individu dengan indeks massa tubuh abnormal. ${ }^{21}$ Pada individu obese cenderung bernapas lewat mulut sehingga membuat rongga hidung terkadang tidak aktif sedangkan pada individu underweight, buruknya nutrisi akan mengganggu imunitas sehingga rentan terkena infeksi saluran napas atas.

Gejala klinis yang ditunjukkan oleh subjek sebagian besar adalah pilek, hidung tersumbat, sakit kepala dan adanya dahak yang mengalir di tenggorok. Hal ini sesuai dengan kriteria European Position Paper on Rhinosinusitis and Nasal Polyps (EPOS) tahun 2007 yang menyatakan diagnosis rinosinusitis meliputi dua atau lebih gejala seperti: hidung tersumbat, sekret hidung (anterior/posterior nasal drip), nyeri wajah dan gangguan penghidu. ${ }^{22}$

Sebagian besar subjek tidak mengalami deviasi septum, yaitu sebanyak 60\% pada Kelompok Perlakuan dan $70 \%$ pada Kelompok Kontrol. Penelitian oleh Mariappan RG et al. menyatakan bahwa deviasi septum nasi memperlambat waktu transpor mukosilia hidung pada sisi konkaf kavum nasi. ${ }^{23}$ Hal ini diperkuat oleh temuan histologi yang menyatakan mukosa septum sisi konkaf mengandung banyak infiltrat inflamasi dan sedikit kelenjar mukosa dibandingkan mukosa septum sisi konveks. ${ }^{23}$

Nilai rerata waktu transpor mukosilia pada rinosinusitis akut dilaporkan bervariasi. Inanli $S$ et al mendapatkan nilai rerata waktu transpor mukosilia pada kelompok rinosinusitis akut sebelum diberikan terapi oxymetazoline topikal sebesar 24,72 $\pm 6,16$ menit sedangkan pada kelompok rinosinusitis akut sebelum diberikan terapi larutan cuci hidung salin isotonis didapatkan rerata waktu transpor mukosilia sebesar $16,84 \pm 9,56$ menit. ${ }^{3}$ Sedangkan pada penelitian yang dilakukan oleh Ural A et al melaporkan nilai rerata waktu transpor mukosilia pada kelompok rinosinusitis akut sebelum diberikan terapi larutan cuci hidung salin isotonis adalah 25 menit sedangkan pada kelompok rinosinusitis akut sebelum diberikan terapi larutan cuci hidung salin hipertonis adalah 30,08 menit. $^{16}$

Waktu transpor mukosilia menunjukkan perbaikan yang bermakna secara statistik antara sebelum terapi dan tiga minggu sesudah terapi ditunjukkan pada kelompok yang mendapat larutan cuci hidung salin hipertonis 3\%, namun perbaikan waktu transpor mukosilia tersebut tidak bermakna secara signifikan jika dibandingkan dengan perbaikan waktu transpor mukosilia pada kelompok yang mendapat terapi antibiotika oral. Penggunaan larutan cuci hidung dengan salin hipertonis telah banyak dilaporkan dan terbukti efektif dapat mempercepat waktu transpor mukosilia dibandingkan dengan larutan salin isotonis. Hal ini dikemukakan oleh Talbot AR et al yang menyatakan perbaikan waktu transpor mukosilia yang bermakna secara statistik setelah pemberian larutan cuci hidung salin hipertonis 3\% dibandingkan kelompok yang mendapat larutan cuci hidung salin isotonis pada orang sehat. ${ }^{24}$ Hasil tersebut dikuatkan oleh penelitian Homer $J$ et al. yang menyatakan perbaikan waktu transpor mukosilia yang berbeda bermakna pada orang sehat yang diberikan larutan cuci hidung salin hipertonis 5\% dibandingkan pemberian larutan cuci hidung salin isotonis. ${ }^{19}$

Larutan salin hipertonis merupakan larutan alkali ringan. Suasana alkali menyebabkan palut lendir berada dalam fase sol sehingga sekret bersifat kurang viskus. Pemberian larutan salin hipertonis menyebabkan keadaan hiperosmolar di saluran pernapasan sehingga terjadi pelepasan kalsium dan prostaglandin $\mathrm{E}_{2}$ dari intraseluler, peningkatan availabilitas adenosine triphosphate pada aksonema silia dan peningkatan ciliary beat frequency. 12,25,26 $^{2}$ Larutan hipertonis juga memiliki efek mukolitik pada konsentrasi $\mathrm{NaCl} 7 \%$, efek antibakteri, serta dapat mengurangi odema mukosa. ${ }^{26-28}$

Penelitian tentang rerata waktu transpor mukosilia pada rinosinusitis akut juga dilakukan sebelumnya oleh Chodankar S et al pada tahun 2014. ${ }^{29}$ Penelitian tersebut dilakukan pada 20 pasien rinosinusitis akut yang dibagi menjadi tiga kelompok, yaitu: Kelompok I $(n=5)$ mendapat terapi antibiotika amoxicillin/clavulanic acid $3 \mathrm{x}$ sehari dan analgetika ibuprofen 2x400mg, Kelompok II $(n=8)$ mendapat terapi antibiotika, analgetika dan larutan cuci hidung salin hipertonis, Kelompok III $(n=7)$ mendapat terapi antibiotika, analgetika dan larutan cuci hidung salin isotonis. ${ }^{29}$ Uji sakarin dilakukan sebelum dan 10 hari sesudah pemberian terapi. Rerata waktu transpor mukosilia pada rinosinusitis akut sebelum terapi adalah 16,34 \pm 1,78 menit. ${ }^{29}$ Perbaikan waktu transpor mukosilia yang bermakna secara statistik ditunjukkan pada kelompok yang mendapat terapi larutan cuci hidung salin hipertonis dan salin isotonis. Akan tetapi, Chodankar S et al tidak melakukan analisis lebih lanjut terhadap perbaikan waktu transpor mukosilia antara kelompok yang mendapat terapi oral tanpa larutan cuci hidung, kelompok yang mendapat larutan cuci hidung salin hipertonis maupun salin isotonis. ${ }^{29}$

Hauptman G dan Ryan MW melakukan penelitian terhadap 80 pasien rinosinusitis akut maupun 
kronis yang mendapat larutan cuci hidung salin isotonis dan hipertonis $3 \%{ }^{30}$ Kriteria inklusi pada penelitian ini adalah skor minimal SNOT-20 sebesar 20. Skor SNOT-20 bekisar antara 0 sampai 100 , dengan skor yang lebih tinggi menunjukkan beratnya gejala. Sebelum uji sakarin dilakukan, pada masing-masing subjek dilakukan penilaian derajat obstruksi hidung menggunakan skala Likert dengan skor berkisar 1 sampai 10, dimana skor 1 menunjukkan tidak ada gangguan sedangkan skor 10 menunjukkan gejala yang sangat mengganggu. Hasil penelitian ini menunjukkan perbaikan waktu transpor mukosilia dan keluhan obstruksi hidung yang bermakna secara statistik pada kelompok yang mendapat larutan cuci hidung salin isotonis maupun hipertonis. ${ }^{30}$

Karakteristik umur dilaporkan memiliki pengaruh yang bervariasi terhadap waktu transpor mukosilia. Meskipun beberapa peneliti menyatakan tidak ada pengaruh faktor umur terhadap waktu transpor mukosilia, namun $\mathrm{Kao} \mathrm{CH}$ et al dan Agius AM at al menyatakan bahwa peningkatan umur berpengaruh terhadap pemanjangan waktu transpor mukosilia. ${ }^{31,32}$ Selain itu, sebagian besar peneliti juga melaporkan bahwa jenis kelamin tidak mempengaruhi waktu transpor mukosilia, akan tetapi penelitian oleh Valia PP et al menyatakan bahwa pada laki-laki terjadi pemanjangan rerata waktu transpor mukosilia dibandingkan dengan perempuan. ${ }^{33}$

Larutan cuci hidung salin isotonis dilaporkan memiliki efek terhadap perbaikan waktu transpor mukosilia pada rinosinusitis kronis yang lebih nyata dibandingkan pada rinosinusitis akut. Pada rinosinusitis akut terjadi perubahan viskoelastisitas sekret, sedangkan pada rinosinusitis kronis telah terjadi kerusakan epitel dan hilangnya struktur silia sehingga terjadi gangguan ciliary beat frequency. ${ }^{4}$ Pemberian larutan cuci hidung salin isotonis pada rinosinusitis akut diharapkan dapat memperbaiki aktivitas mukosilia hidung secara langsung dengan cara membersihkan sekret dan bahan iritan yang masuk melalui udara pernapasan, menjaga kelembaban, mengurangi odema mukosa dan mediator inflamasi, sedangkan pada rinosinusitis kronis, larutan cuci hidung salin isotonis dapat memperbaiki aktivitas mukosilia dengan cara meningkatkan ciliary beat frequency. ${ }^{13,16}$

Penggunaan larutan cuci hidung dengan salin isotonis pada rinosinusitis akut masih banyak diperdebatkan. Pada penelitian ini tidak terjadi perbaikan waktu transpor mukosilia yang bermakna dengan penggunaan larutan cuci hidung salin isotonis pada rinosinusitis akut. Akan tetapi penelitian sebelumnya menunjukkan bahwa pemberian larutan cuci hidung nampaknya lebih menunjukkan hasil yang bermakna terhadap perbaikan waktu transpor mukosilia melalui peningkatan ciliary beat frequency. ${ }^{16}$

Keterbatasan penelitian ini adalah sebagai berikut: 1 . Tidak dilakukannya pembagian subjek berdasarkan derajat beratnya penyakit yang dapat dihitung menggunakan skor SNOT-20 maupun derajat beratnya obstruksi hidung yang dapat diukur menggunakan skala Likert maupun peak nasal inspiration flow, 2. Tidak dilakukannya metode matching terhadap variabel umur, jenis kelamin dan waktu transpor mukosilia sehingga distribusi variabel tersebut pada ke dua kelompok perlakuan tidak merata.

\section{SIMPULAN}

Berdasarkan hasil penelitian ini dapat disimpulkan bahwa penambahan larutan cuci hidung salin isotonis pada rinosinusitis akut memiliki efek waktu transpor mukosilia yang sama dengan pemberian antibiotika, dekongestan dan mukolitik tanpa larutan cuci hidung salin isotonis.

\section{KONFLIK KEPENTINGAN}

Tidak terdapat konflik kepentingan dalam penulisan laporan penelitian ini.

\section{ETIKA PENELITIAN}

Penelitian ini telah mendapatkan persetujuan etik dari Komisi Etik, Fakultas Kedokteran, Universitas Udayana, RSUP Sanglah, Bali, Indonesia sebelum penelitian berjalan.

\section{PENDANAAN}

Tidak ada

\section{KONTRIBUSI PENULIS}

Seluruh penulis memiliki kontribusi yang sama baik dari tahap penyusunan kerangka konsep, pencarian dan pengumpulan data, analisis data, hingga interpretasi dan melaporkan hasil penelitian.

\section{DAFTAR PUSTAKA}

1. Ramon P, Victor-John C, Benjamin S. A comparison of the mucus transport time between filipinos living in urban and rural areas. The Philippine Journal of Oto-RhinoLaryngology Head \& Neck Surgery. 1999;14(3):2-6.

2. Naxakis S, Athanasopoulos I, Vlastos IM, Giannakenas C, Vassilakos P, Goumas P. Evaluation of nasal mucociliary clearance after medical or surgical treatment of chronic rhinosinusitis. Eur Arch Otorhinolaryngol. 2009;266(9):1423-6. 
3. Inanli S, Oztürk O, Korkmaz M, Tutkun A, Batman C. The effects of topical agents of fluticasone propionate, oxymetazoline, and $3 \%$ and $0,9 \%$ sodium chloride solutions on mucociliary clearance in the therapy of acute bacterial rhinosinusitis in vivo. Laryngoscope. 2002;112(2):320-5.

4. Georgitis JW. Nasal hyperthermia and simple irrigation for perennial rhinitis. changes in inflammatory mediators. Chest. 1994;106(5):1487-92

5. Naclerio RM, Gungor A. Etiologic Factors in Inflammatory Sinus Disease. In: Kennedy DW, Bolger WE, Zinreich SJ. Editors: Disease of The Sinus, Diagnosis and Management. London: B.C. Decker Inc. 2001, p. 47-55.

6. Busquets JM, Hwang PH. Nonpolypoid Rhinosinusitis: Classification, Diagnosis, and Treatment. In: Bailey BJ and Johnson JT. Editors: Head \& Neck Surgery-Otolaryngology. $4^{\text {th }}$. Ed. Philadephia: Lippincott Williams \& Wilkins. 2006, p. 405-16.

7. Metson RB. The Harvard Medical School Guide to Healing Your Sinuses. New York: McGraw-Hill. 2005, p. 3-33.

8. Levine HL. Diagnosis and Management of Rhinosinusitis. In: Levine HL and Clemente MP. Editors: Sinus Surgery Endoscopic and Microscopic Approaches. New York: Thieme. 2005, p. 90-9.

9. Mulyarjo. Diagnosis Klinik Rinosinusitis. Naskah Lengkap Pendidikan Kedokteran Berkelanjutan IV Ilmu Kesehatan Telinga Hidung Tenggorok-Kepala Leher FK Unair. Surabaya. 2004, p. 17-25.

10. Thaler ER. Management of Acute Rhinosinusitis. In: Kennedy DW, Bolger WE, Zinreich SJ. Editors: Disease of The Sinus, Diagnosis and Management. London: B.C. Decker Inc. 2001, p. 149-54.

11. Conrad DA. Medical Management of Acute Sinusitis. In: Brook I. Editor: Sinusitis from Microbiology to Management. New York: Taylor \& Francis Group. 2006, p. 203-17.

12. Garavello W, Romagnoli M, Sordo L, Gaini RM, Di Berardino C, Angrisano A.. Hypersaline nasal irrigation in children with symptomatic seasonal allergic rhinitis: a randomized study. Pediatr Allergy Immunol. 2003;14(2):140-3.

13. Papsin B, McTavish A. Saline nasal irrigation: its role as an adjunct treatment. Can Fam Physician. 2003;49:168-73.

14. Rabago D, Zgierska A. Saline nasal irrigation for upper respiratory conditions. Am Fam Physician. 2009;80(10):1117-9.

15. Achilles N, Mösges R. Nasal Saline irrigations for the symptoms of acute and chronic rhinosinusitis. Curr Allergy Asthma Rep. 2013;13(2):229-35

16. Ural A, Oktemer TK, Kizil Y, Ileri F, Uslu S. Impact of isotonic and hypertonic saline solutions on mucociliary activity in various nasal pathologies: clinical study. J Laryngol Otol. 2009;123(5):517-21.

17. King D, Mitchell B, Williams CP, Spurling GK. Saline nasal irrigation for acute upper respiratory tract infections. Cochrane Database Syst Rev. 2015;(4):CD006821.

18. Sakakura Y, Ukai K, Majima Y, Murai S, Harada T, Miyoshi Y. Nasal mucociliary clearance under various conditions. Acta Otolaryngol. 1983;96(1-2):167-73.

19. Homer JJ, England RJ, Wilde AD, Harwood GR, Stafford ND. The effect of $\mathrm{pH}$ of douching solution on mucociliary clearance. Clin Otolaryngol Allied Sci. 1999;24(4):312-5.
20. Ho JC, Chan KN, Hu WH, Lam WK, Zheng L, Tipoe GL, et al. The effect of aging on nasal mucociliary clearance, beat frequency and ultrastructure of respiratory cilia. Am J Respir Crit Care Med. 2001;163(4):983-8.

21. Valdez RJL, Cruz ES. Nasal Mucociliary Clearance (Mucus Transit Time) and Abnormal Body Mass Index (Underweight and Obese) in Filipino Adult Volunteers. Philippine Scientific Journal. 2009;42(1):10-3.

22. Fokkens WJ, Lund VJ, Mullol J, Bachert C, Alobid I, Baroody F, et al. European Position Paper on Rhinosinusitis and Nasal Polyps 2012. Rhinol Suppl. 2012;23:3

23. Mariappan RG, Dhanalakshmi M, Mathaikutty DM, Shanmugam R, Shanmugam U, Swaminathan B, et al. Clinico-Pathological Correlation and the Effects of Septal Surgery on Nasal Mucociliary Clearance. Sch J App Med Sci. 2014;2(5C):1691-5.

24. Talbot AR, Herr TM, Parsons DS. Mucociliary Clearance and Buffered Hypertonic Saline Solution. Laryngoscope. 1997;107(4):500-3.

25. Daviskas E, Anderson SD, Gonda I, Eberl S, Meikle S, Seale JP, et al. Inhalation of hypertonic saline aerosol enhance in asthmatic and healthy subjects. Eur Respir J. 1996;9(4):725-32.

26. Shoseyov D, Bibi H, Shai P, Shoseyov N, Shazberg G, Hurvitz H.. Treatment with hypertonic saline versus normal saline nasal wash of pediatric chronic sinusitis. J Allerg Clin Immunol. 1998;101(5):602-5.

27. Boek WM, Keleş N, Graamans K, Huizing EH. Physiologic and hypertonic saline solutions impair ciliary activity in vitro. Laryngoscope. 1999;109(3):396-9.

28. Lee SH, Song JS, Lee SH, Hwang SJ, Lee HM. Effect of hypertonic seawater (Sinomarin) on mucociliary clearance in normal subjects. J Rhinol. 2003;10(1,2):19-22.

29. Chodankar S, D'sa C, Tiwari M, Goel HC, Andhale-Goa D. 2014. Impact of isotonic and hypertonic saline on mucociliary activity in various nasal pathologies. National Journal of Otorhinolaringology and Head \& Neck Surgery. 2014;2(11): 9-11.

30. Hauptman G, Ryan MW. The effect of saline solutions on nasal patency and mucociliary clearance in rhinosinusitis patients. Otolaryngol Head Neck Surg. 2007;137(5):815-21.

31. Kao CH, Jiang RS, Wang SJ, Yeh SH. Influence of age, gender and ethnicity on nasal mucociliary clearance function. Clin Nucl Med. 1994;19(9):813-6.

32. Agius AM, Smallman LA, Pahor AL. Age, Smoking and Nasal Ciliary Beat Frequency. Clin Otolaryngol Allied Sci. 1998;23(3):227-30.

33. Plaza Valía P, Carrión Valero F, Marín Pardo J, Bautista Rentero D, González Monte C.. Saccharin test for the study of mucociliary clearance: reference values for a Spanish population. Arch Bronconeumol. 2008;44(10):540-5.

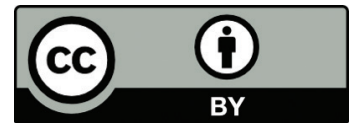

This work is licensed under a Creative Commons Attribution 